\title{
Morphometry of lunette dunes in the Tirari Desert, South Australia
}

https://doi.org/10.1515/geo-2018-0035

Received May 23, 2018; accepted July 31, 2018

Abstract: Morphometry and formation processes are key research problems in the study of aeolian sandy landforms. Based on morphometric parameters inferred from satellite images and the calculation of the drift potential (DP), we examined general characteristics of lunette dunes in the Tirari Desert, South Australia, along with their morphometry and formation processes to determine how this landform type initially formed and its relationship to surrounding linear dune distribution. Results show that the morphometric parameters of lunette dunes and connective lake systems exhibit moderate correlations. It suggests that the morphology of these dunes is controlled by the lakes. Spatially, the lunette dunes present regular arrangement, and the strike of their alignment are approximately in accordance with the linear dunes. The calculated DP implies that the lunette dunes developed under a lowwind-energy environment, which is a wind regime similar to that required for the formation of the surrounding linear dunes. Even though, the resultant DP demonstrates that the summer wind should be responsible for the growth of the lunette dunes. However, accompanied with the repeated drying of lakes and even its disappearance during the dune development process, it not only contributes to the development of lunette dunes but also promotes their transformation to linear dunes.

Keywords: Lunette dunes, Morphometric parameters, Drift potential, Tirari Desert, South Australia

\footnotetext{
${ }^{\star}$ Corresponding Author: Zhengyao Liu: School of Geography and Tourism, Shaanxi Normal University, No.620 West Chang'an Avenue, 710119, Chang'an District, Xi’an, Shaanxi Province, China, E-mail: liuzhengyaolzy@163.com

Zhibao Dong, Xujia Cui: School of Geography and Tourism, Shaanxi Normal University, No.620 West Chang'an Avenue, 710119, Chang'an District, Xi'an, Shaanxi Province, China
}

\section{Introduction}

Morphometry and formation processes are key research problems for the study of aeolian-driven sandy landforms; its theoretical basis is that the process determines the form and the form reflects the process [1]. In different areas, aeolian-driven sand transportation processes are affected by different factors, such as varying wind regimes, ecological systems, and hydrological systems, which result in different dune morphology [2].

Australia has the second largest subtropical desert area in the world. These deserts are covered by enormous, counter-clockwise turbine-shaped linear dunes [3, 4], which have subsequently aroused widespread attention and research interest by aeolian geomorphologists. Much research has been conducted thus far on the morphology and formation of linear dunes. For instance, Wasson et al. [5] studied the type, spacing, and orientation of linear dunes; Fitzsimmons et al. [4] researched the timing of linear dune activity; and Telfer et al. [6] discussed the morphodynamics, boundary conditions, and pattern evolution within a vegetated linear dune field. In addition to linear dunes, Australian deserts are also composed of transverse dunes and irregular dunes, such as crescent dunes [7] and lunette dunes [8], but, in general, there has been little research on these dune types [10]. Lunette dunes are sand dunes that typically form on the leeward side and feature a wind-sculpted crescent shape [8], such as the megadunes and lake systems found in the Badain Jaran Desert in China [10, 11]. Compared to these megadunes, lunette dunes are relatively small and their edges are flanked by a wide range of linear dunes. Thus, why do lunette dunes form around linear sand dunes, and how do they relate to linear dunes? Based on these questions, we selected lunette dunes in the Tirari Desert as the research object of this study. It is hypothesized that this type of dune-lake system is likely to assist in the development of linear sand dunes, especially in arid climates. As proposed by Hesse et al. [12], in early 25,000 BP water levels in arid areas of central Australia decreased, and the degree of soil salinization subsequently increased, resulting in the formation of clay-rich sandy sediments, which laid 


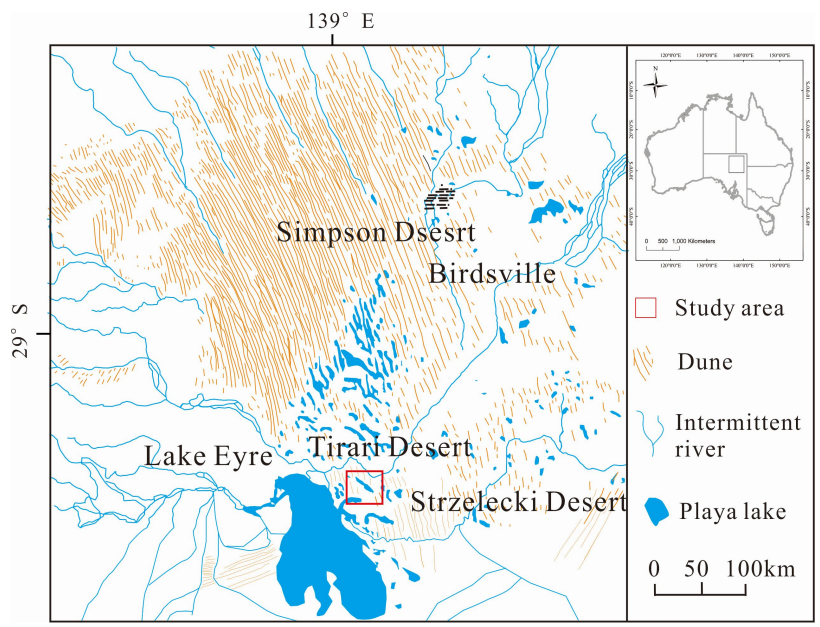

Figure 1: The location of the study area

the foundation for the formation of large-area linear sand dunes as well as novel and unique geomorphological features.

In this study, we used data obtained from satellite imagery to study the morphological characteristics of lunette dunes in the Tirari Desert. The aim of this study was to understand the relationship between this dune-lake system and try to explain its relationship to linear dunes. This study could provide new information to further discern the formation and evolution of linear dunes in Australia.

\section{Regional setting}

The Tirari Desert is located in South Australia and covers an area of $15,250 \mathrm{~km}^{2}$ (Fig. 1). It stretches $212 \mathrm{~km}$ from north to south and $153 \mathrm{~km}$ from east to west. The desert is adjacent to the Simpson Desert to the north, the Strzelecki Desert to the southeast, and the Sturt Stony Desert to the east. The western, eastern, and northern section of this desert is bordered by Lake Eyre, and Cooper Creek flows through its interior. Because little research has been conducted on the Tirari Desert to date, some scholars have included it in studies related to the Strzelecki Desert [4, 13], while other scholars have regarded it as an extension of the Simpson Desert [14]. In contrast to these studies, because the Tirari Desert exhibits unique hydrological and geomorphological characteristics that are distinctly different from those of the adjacent deserts [13], we regarded the Tirari Desert as a separate entity. This desert is characterized by large dune fields orientated in a north-south direction and a myriad of salt lakes in the northeastern and eastern sections of Lake Eyre. The environmental conditions of Cooper Creek are extreme, being one of the hottest and driest places in Australia. The average annual rainfall is $125 \mathrm{~mm}$; the annual average temperature is $22.6^{\circ} \mathrm{C}$ (Fig. 2a), and the interannual variability is very high for both precipitation and temperature [15]. The average wind speed is $4.6 \mathrm{~m} \mathrm{~s}^{-1}$, which is strong in the winter $\left(5.2 \mathrm{~m} \mathrm{~s}^{-1}\right)$ and weak in the summer $\left(3.2 \mathrm{~m} \mathrm{~s}^{-1}\right)$; the strongest winds occur in January and February. The mean sea-level pressure is $1015 \mathrm{hPa}$, the highest pressure occurring in July $(1021 \mathrm{hPa})$ and the lowest occurring in December $(1008 \mathrm{hPa})$. Despite the harsh environment, this desert still harbors unique biological communities that have adapted to such conditions, namely, deep-rooted or xerophilic vegetation, including Acacia ligulata and Zygochloa paradoxa, and typical Australian desert animals, such as lizards, snakes, insects, and koalas [16]. The lunette dunes investigated in this study are located to the north of Lake Koolkootinnie, which is a large playa lake around Lake Eyre. It is $108.14 \mathrm{~km}$ long with an area of $104.85 \mathrm{~km}^{2}$, having formed by means of palaeodrainage, surrounded by a wide range of linear sand dunes [17]. These linear dunes are approximately $5 \mathrm{~km}$ long, $30 \mathrm{~m}$ wide, and approximately $1 \mathrm{~m}$ high. They move in a northwest to southeast direction and slowly eastward [18].

\section{Materials and methods}

\subsection{Morphological parameters}

\subsubsection{Parameter measurement}

In this study, we mainly used WorldView-2 satellite imagery (http://www.zj-view.com) at a resolution of $0.5 \times 0.5 \mathrm{~m}$ and Google Earth images in ArcGIS 10.2 (www.esri.com) to draw and measure morphological parameters. Squares were randomly selected in the northern section of Lake Koolkootinnie, which is situated far from potential disturbances. The study area is located at $27^{\circ} \mathrm{S}$ and $137^{\circ} \mathrm{E}$. In total, the study area is composed of 60 sand dunes and 60 lakes. We measured the left wing length, right wing length, width, center angle, direction, area, and spacing of each dune, as well as the length, width, and area of the lake (Fig. 2). However, due to technical limitations, we did not measure sand dune height. Instead, we measured the average area of two adjacent sand layers according to (area $1+$ area 2)/2, which was used to define the relationship between sand area and dune spacing $[10,19,20]$. 


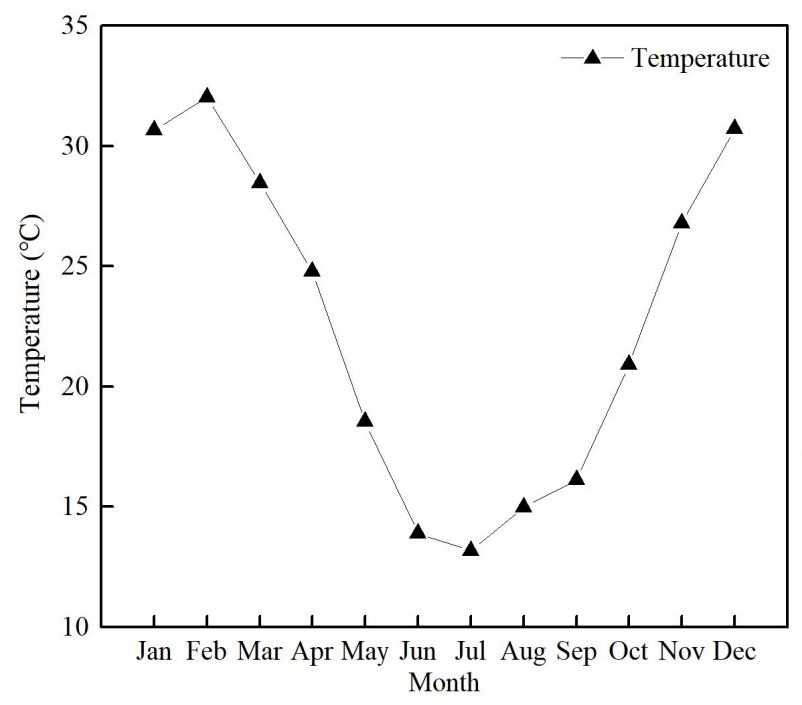

Figure 2: Temperature and sea-level pressure of the study area

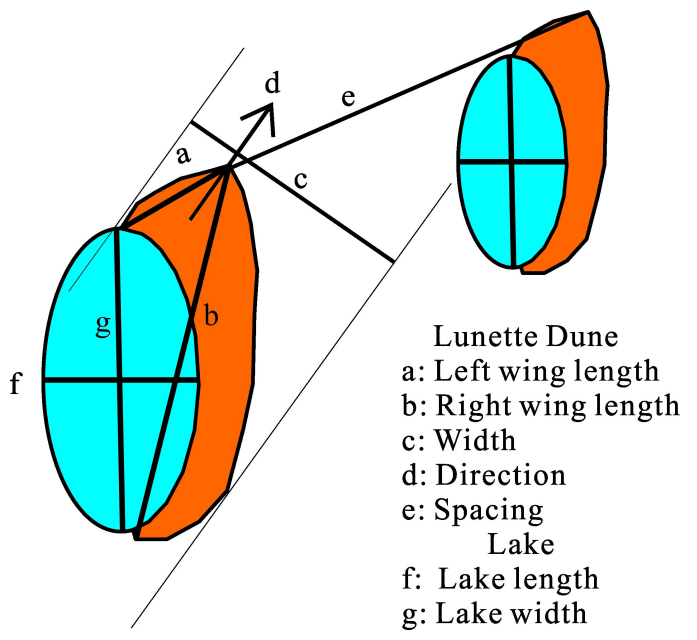

Figure 3: Illustration of the geometric parameters used to study sand areas (a, b, c, d, and e) and associated lakes ( $f$ and g)

\subsubsection{Parameter calculation}

First, according to a range of parameters, mathematical statistics were used to determine the cumulative percentage. Then, the coefficient of variation (CV) was calculated to compare the degree of dispersion and data stability for different dimensions or different means [21]. Among these, the greater the $\mathrm{CV}$ value is, the greater the degree of dispersion will be, namely, the greater the volatility of the data. Conversely, the smaller the $\mathrm{CV}$, the smaller the degree of dispersion will be, namely, the more stable the data. When the $\mathrm{CV}$ is less than 1 , the average amplitude of the change in the threshold estimation value is smaller than the aver-

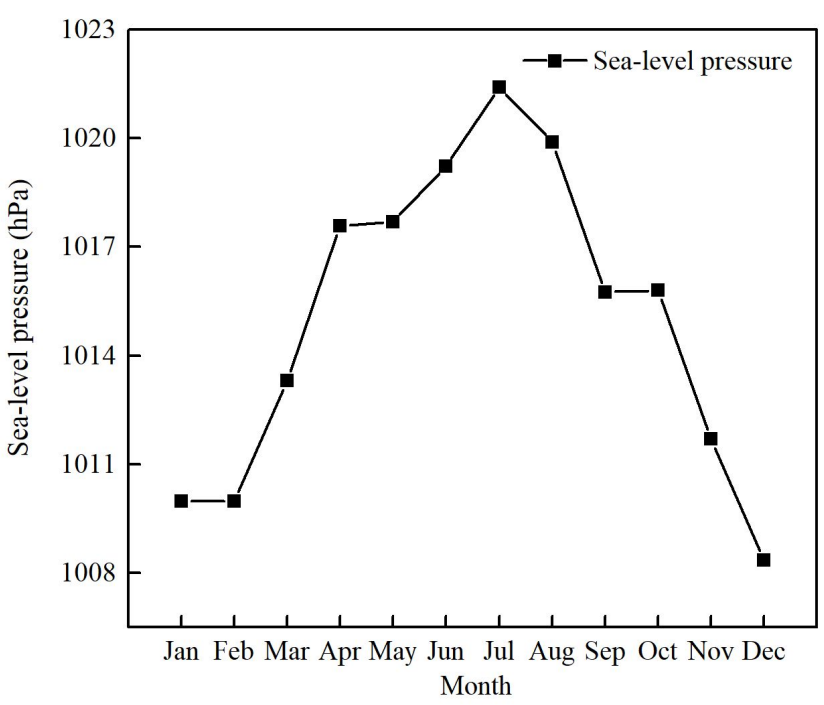

age value, and the stability is better. When the CV is greater than 1, the average amplitude of the change in the threshold estimation value is greater than the average value, and the stability is poor. The specific calculation is as follows:

$$
C_{v}=\frac{\sigma}{\bar{x}} \star 100 \%=\frac{\sqrt{\frac{1}{n-1} \sum_{i=1}^{n}\left(x_{i}-\bar{x}\right)^{2}}}{\bar{x}} \star 100 \%
$$

where $n$ is the number of samples; $\sigma$ is the standard deviation of the samples; $\mathrm{x}_{i}$ is the value of the morphological parameter; and $x$ is the average of the morphological parameter.

Subsequently, correlation analysis was conducted on the various lunette dune and lake parameters. Finally, the SPSS 24.0 canonical correlation analysis (CCA) feature was used to further reflect the typical variables in the relationship between the two variable groups. The dominant factor was determined by the magnitude of the absolute value of the typical load, which was used to determine the interaction between lake and sandy sediment.

\subsection{Meteorological parameters}

Meteorological data from the National Standard Climate Station, which is located on the eastern side of the study area, were obtained from the National Weather Data website (http://data.cma.cn/). Airport weather station data are more accurate, and distance information was accordingly taken from the latest weather station data in the study area. In accordance to the spatiotemporal continuity and 
reliability of the data, the selected average daily meteorological data was taken from January 1, 2016, to December 31, 2016, and included the average wind speed, wind direction, average precipitation, and sea-level pressure. Wind speed was measured at a height of $10 \mathrm{~m}$. Drift potential (DP) calculations were used to reflect the influence of the wind on the landscape according to the standards employed to determine the wind energy environment.

\section{Results}

\subsection{Morphometry}

A unique lunette dune assemblage of approximately $20 \mathrm{~km}^{2}$ in area is located $2 \mathrm{~km}$ to the north of Koolkootinnie Lake. In 2015, we collected 1984 images (Fig. 4a) from Google Earth and a research area image (Fig. 4b) from the WorldView-2 satellite. The images showed that some weak geomorphologic changes occurred in the study area over the last $30 \mathrm{yr}$. These changes were due to evapotranspiration and the wind regime around the lake, which had a significant impact on the concomitant sandy areas. The images also showed the existence of an intermittent river that flowed in a northeast to southwest direction before eventually entering the lake within the sand dune area.

Greater than $60 \%$ of the study area was covered by lunette dunes, which differed from the vast distribution of linear dunes in the surrounding areas. However, the arrangement of these lunette dunes (10 parallel strip lines; Fig. 5) exhibited some similarity with the surrounding linear dunes. It was therefore speculated that this could be related to the early evolution of the linear dunes. Generally, the length of the left wing of the sand dunes was between 10 30 m; the length of the right wing was between $20 \sim 80 \mathrm{~m}$; and the width was $15 \sim 25 \mathrm{~m}$. In comparison, the length of the lakes is approximately $10 \sim 30 \mathrm{~m}$, and the width of the lakes is approximately 10 20 m. In this region, $81 \%$ of the sand dune area is concentrated within $1000 \mathrm{~m}^{2}$, and the distribution is relatively uniform, gradually increasing from small to large. The direction of the left wing of the sand dunes was approximately from $210^{\circ}$ to $240^{\circ}$; the direction of the right wing was approximately from $150^{\circ}$ to $180^{\circ}$; the center angle between the left and right wings was approximately from $40^{\circ}$ to $60^{\circ}$; and the direction was mainly between approximately $15^{\circ}$ to $30^{\circ}$. The direction of the right wing was parallel to the direction of the entire line of dunes, and the length of the right wing was the same as the length of the lake. Furthermore, $\mathrm{CV}$ values ranged between 0.48 and 0.89 . The morphology was relatively uniform, and, because of this, fluctuation was extremely small.

\subsection{Correlations}

Previous studies from Ash and Wasson [22], Lancaster [23], and Dong et al. [10] reported a good correlation between dune spacing and height. There is also evidence that spacing is more important than sand dune height on a landscape developmental pattern, which has to do with the association with the substrate type (availability) of sediments [5].

Therefore, we used correlation analysis to explore the relationship between lakes and lunette dunes. First, the left length of the dune and the lake width (Fig. 6a) and the right length of the dune and the lake length (Fig. 6b) were all linearly dependent, which indicated that the dunes generally extended alongside the right lake bank. Second, both sand dune area and lake area showed a strong linear correlation (Fig. 6c), which indicated that the larger the lake area, the larger the sand area will be. In addition, the length of the lake showed a linear correlation to dune area, but the strength of the relationship was less than that of the lake area (Fig. 6d). The above mentioned studies indicated that the desert area was mainly affected by the lake area, but its development was closely associated with lake length.

We also found that the left wing length of the dunes was approximately half the length of the right wing, the width of the dune was approximately 0.6 of the length of the right wing, and the width of the lake was approximately 0.5 of the length of the lake. Based on the linear relationship of the left wing length and width of the dunes (Fig. 6e), the left side in itself could control the length and width of dunes, and the lesser that dune parameter relationships are, the more obvious it becomes that a large area composed of multiple sand dunes can occur under unstable relationships. Moreover, in the study area, the size and spacing of the dune area were not correlated (Fig. 6f), which indicated that the distance between the dunes was generally small. Therefore, the lake size was the dominant factor responsible for the characteristics of the sandy area. The greater the length of the long axis of the lake is, the greater the long axis of the sand area will be.

To further verify the degree of influence of the correlation, we configured the parameters for the CCA and set the basic parameters, such as lake length, lake width $\mathrm{X}$, and sand dune area $\mathrm{Y}$, as variables. The calculated CCA between the two groups of variables was $0.927(\mathrm{P}<0.01)$, 


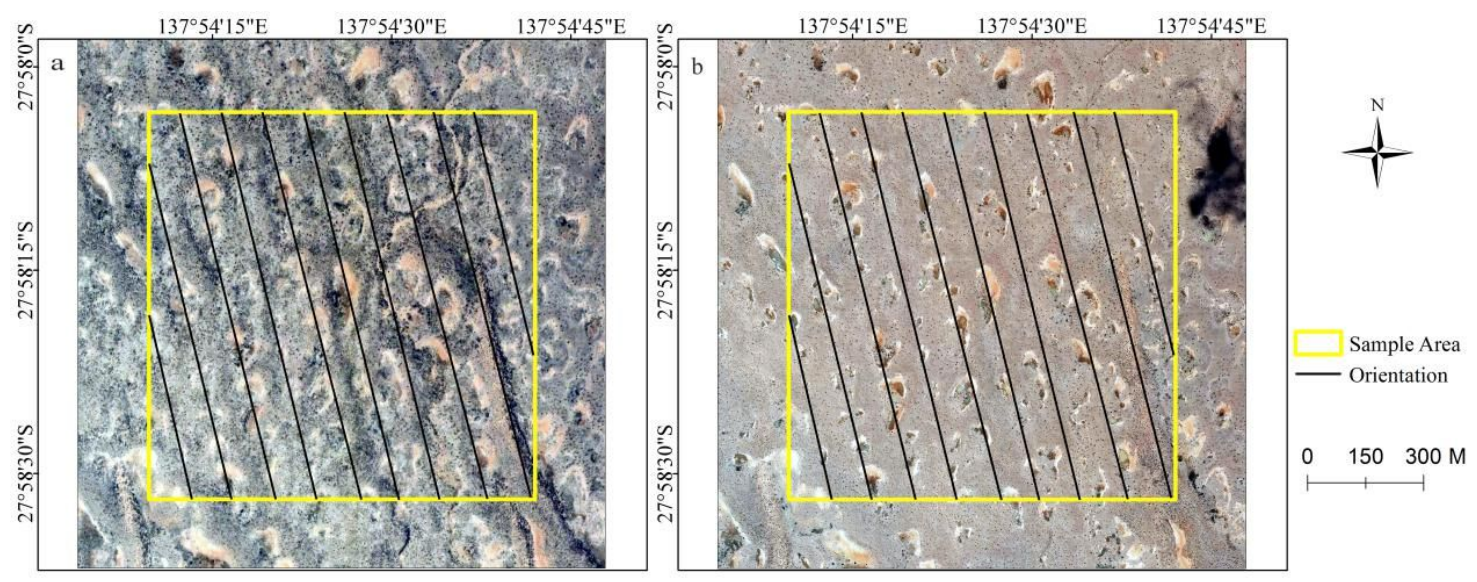

Figure 4: (a) Google Earth image of the study area in 1984 and (b) WorldView-2 satellite image of the study area in 2015 at a resolution of $0.5 \mathrm{~m} \times 0.5 \mathrm{~m}$
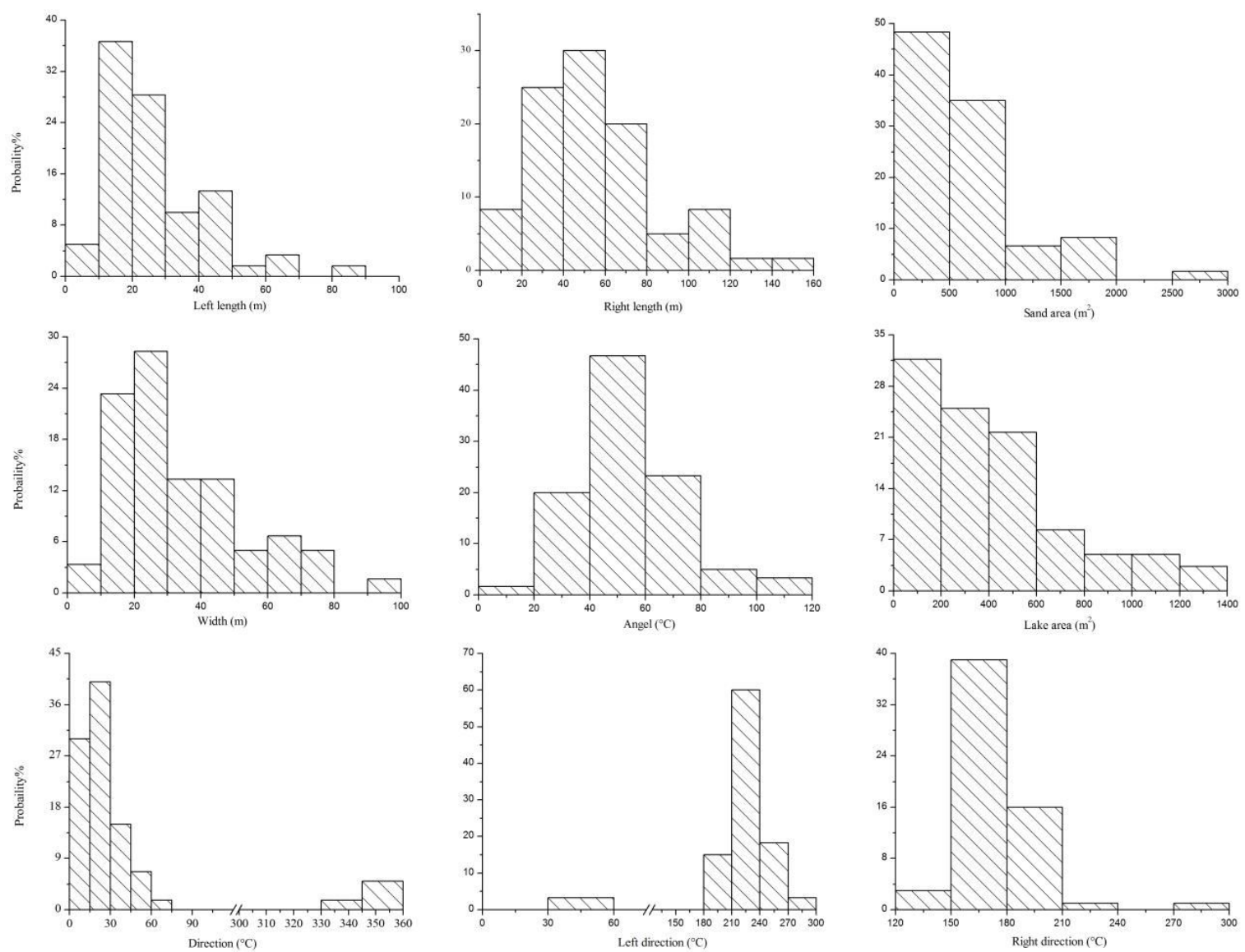

Figure 5: Cumulative probability plots of basic parameterss

suggesting that both groups showed an extremely obvious linear relationship, and the parameters of the factors had obvious effects on the sand dune area. The absolute value of the typical load indicated the weight of the influence of each factor (Table 1). The maximum impact of the lake area can be obtained through the absolute value of the typical load, followed by the right-wing dune length, which also indicated that the lake area had the greatest influence on the sand dune area. 

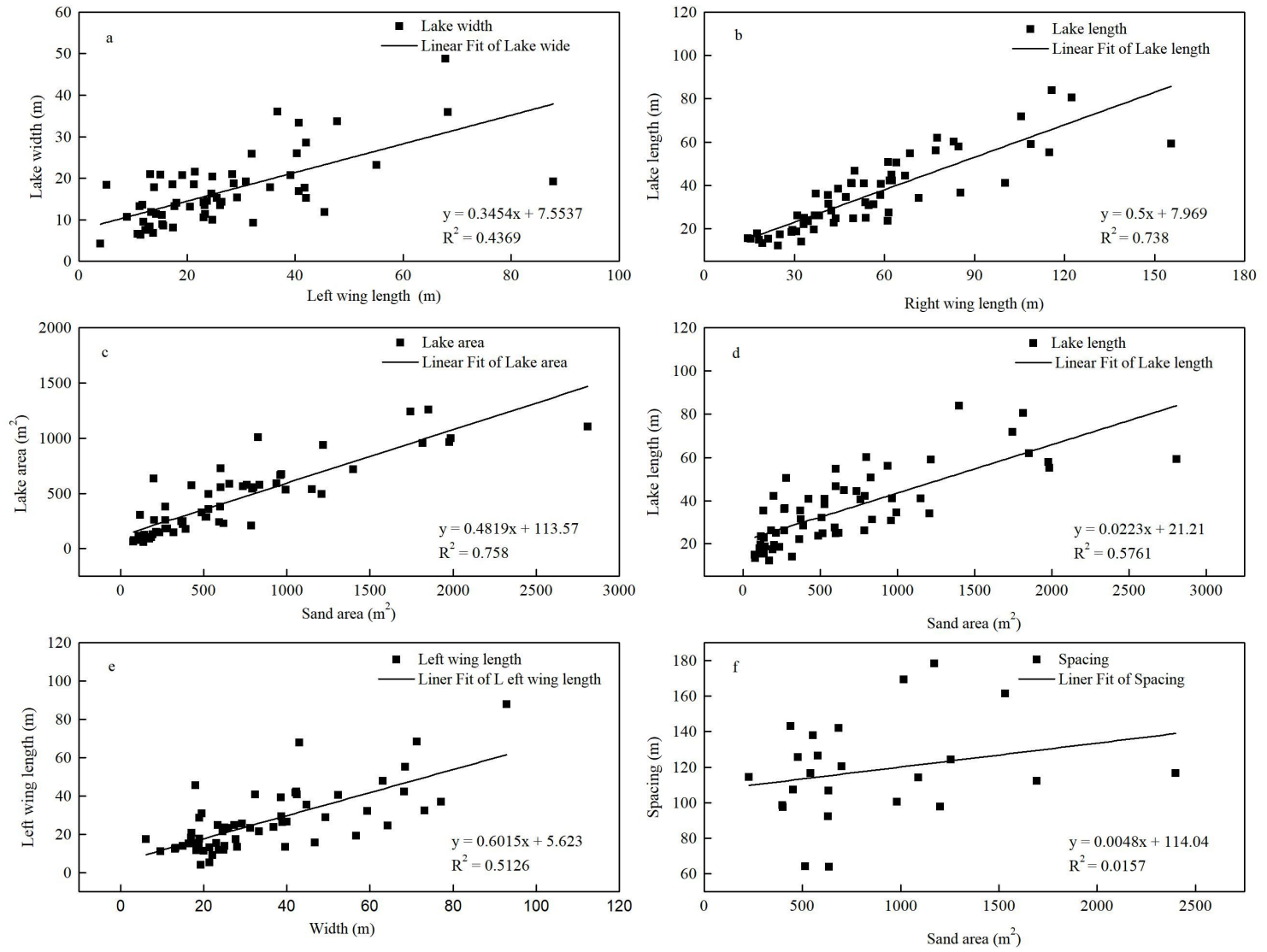

Figure 6: Correlation representation of various parameters
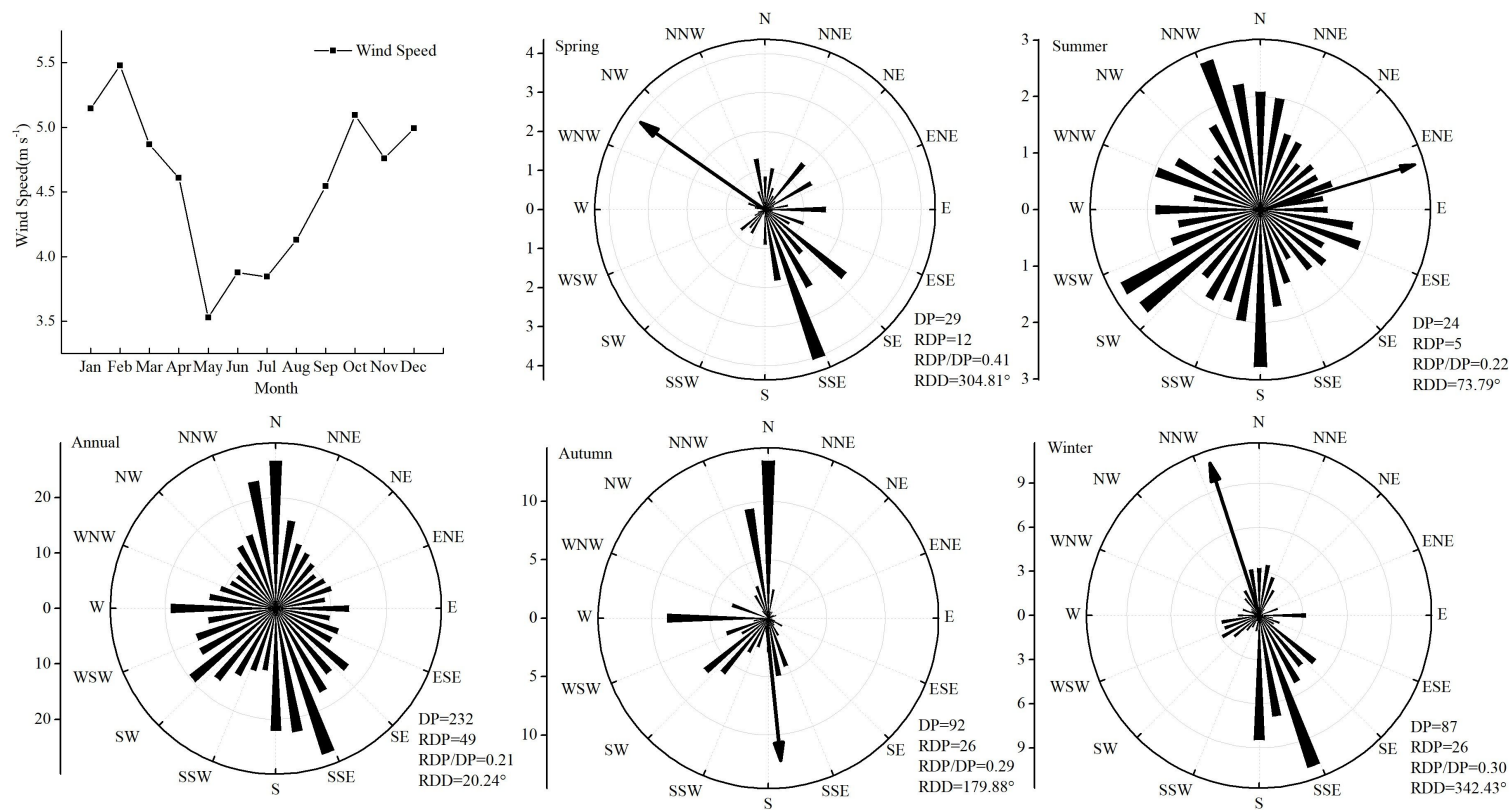

Figure 7: Wind speed during each month and wind regime parameters (DP, drift potential; RDD, resultant drift direction; RDP, resultant drift potential; RDP/DP, directional variability) throughout the four seasons and for the year as a whole. Arrows represent RDD 
Table 1: Typical load values from canonical correlation analysis for the relationships between lake and sand area parameter values and CV

\begin{tabular}{ccccccc}
\hline & \multicolumn{5}{c}{ Parameter } \\
items & Left wing & Right wing & Sand width & Lake length & Lake width & Lake area \\
\hline load values & +0.60 & +0.92 & +0.79 & +0.82 & +0.48 & +0.94 \\
CV & +0.61 & +0.53 & +0.55 & +0.48 & +0.50 & +0.75 \\
\hline
\end{tabular}

\subsection{Wind speed and sand drift potential}

Meteorological airflow and wind regime characteristics constitute the main dynamic factors of aeolian transport. The surface wind regime affects the formation of the dune landscape pattern and the evolution of the main dynamic factors [24-27]. Given that the study area is located within the Southern Hemisphere, the area is controlled by the return of a high-pressure system in summer from the Indian Ocean to the central region of the continent, and the surface is affected by northerly and southwesterly winds. During the winter, the surface of the study area is mainly controlled by southeasterly winds that move across the desert. As shown in Fig. 7, winter wind speed is low $\left(3.9 \mathrm{~m} \mathrm{~s}^{-1}\right)$, and wind speed is the lowest in May, while summer wind speed is high $\left(5.2 \mathrm{~m} \mathrm{~s}^{-1}\right)$, and the maximum wind speed occurs in February. The study area is located within a lowwind-energy environment with an average annual DP of $232 \mathrm{VU}$ (Fig. 7). Autumn DP is highest (92 VU), followed by winter ( $81 \mathrm{VU})$, the lowest DP occurs in summer (only $24 \mathrm{VU}$ ). The resultant drift potential (RDP) is $49 \mathrm{VU}$, and the resultant drift direction (RDD) is southwest. The direction coefficient (RDP/DP) is between 0.22 and 0.41 . Winter is characterized by a strong southeasterly wind, spring by an abated southeasterly wind, autumn by a slightly westerly to southwesterly wind, and summer by a strong northerly wind according to the minimum direction coefficient. Therefore, wind is most unstable throughout the year when it moves in a northwest-southeast direction. Linear sand dunes surrounding and within the lee of the lake (the west bank in this case) accumulate sand material, especially during summer and autumn when accumulation is strongest.

\section{Discussion}

All of the Earth's deserts are unique, and sand dunes are the main landforms of most deserts. In a desert environment, three factors will trigger the activation of dunes: sediment supply, strong winds, and low vegetation $[23,28$, 29], and these factors will increase the magnitude of de- sertification and consequently have disastrous effects on the ecological environment.

Lunette dunes are shaped like crescent dunes, but they form in the opposite direction of windward and leeward slopes, with two wings that develop along the lakeside. As lakes dry up into lacustrine deposits during summer and autumn, sediment is redeposited on the east bank of lakes, which subsequently results in the emergence and development of right-wing dunes. Southeasterly winds dominate in spring and winter, and sediments pile up on the west bank of lakes, which allows for the development of the left wing. However, the lakes are in a more southeasterly or northwesterly direction of the basin that feeds them given that monsoon strength is greater during summer and autumn; thus, the eastern section of the lake (lake length) is more affected by wind and sediment accumulation than the western section of the lake (lake width). Moreover, the morphological features of the dunes exhibited a center angle parallel to the direction of the surrounding sand dunes.

According to Fitzsimmons et al. [4], linear dunes of the Tirari Desert were formed by palaeochannels, alluvial plains, and floodplains. The accumulation of lunette dunes associated with these lakes derived from river and fluvial lacustrine sediment during the Late Quaternary. These lakes did not completely dry up but gradually separated from larger lake systems, and they continue to contribute to the modern development of sand dunes [31]. Because the development of linear sand dunes in the study area is closely associated with ancient drainage systems, the lunette dunes represent the mid stage of Tirari Desert development, which eventually formed linear dunes similar to the surrounding landscape.

\section{Conclusions}

In this study, we examined morphometric characteristics and the wind regime of lunette dunes in the Tirari Desert, and from this investigation have drawn three key insights.

(1) The Australian Tirari Desert lunette dune area has an average temperature of $22.6^{\circ} \mathrm{C}$, a mean sea-level pres- 
sure of $1015 \mathrm{hPa}$, an average left wing length of $26 \mathrm{~m}$ at an approximate orientation of $220^{\circ}$, and a right wing length of $55 \mathrm{~m}$ at an approximate orientation of $177^{\circ}$. The lunette dunes have an average width of $34 \mathrm{~m}$, an area of $650 \mathrm{~m}^{2}$, a center angle between the left and right wings of approximately $40^{\circ} \sim 60^{\circ}$, and a center direction mainly between $15^{\circ}$ and $30^{\circ}$. The lakes in this area have an average length of $35 \mathrm{~m}$, an average width of $17 \mathrm{~m}$, and an average area of $245 \mathrm{~m}^{2}$. The right-wing direction of lunette dunes is basically parallel to the overall pattern of the sand dunes surrounding them, and the length of the right wing is similar to the length of the lake. The CV of each parameter was between 0.48 and 0.89 , with a relatively uniform configuration and low volatility.

(2) The morphological parameters showed that the dunes stretch along the right bank of the lake, and the linear correlation indicated that the length of left-wing dunes could in itself determine the width of the dunes. The desert area is primarily affected by lake area, and the development process is closely associated with the length of the lake. The size and spacing of the dunes were not correlated.

(3) The lunette dunes investigated in this study were formed in a low-wind-energy environment. The average wind speed was $4.6 \mathrm{~m} \mathrm{~s}^{-1}$, and the average DP was 232 VU. Throughout the year, lunette dunes form similarly to the linear dunes around them with a northwest-southeast wind direction. We can basically confirm that the lunette dunes will gradually continue to evolve into a linear dune connected with the periphery of the lakes.

\section{References}

[1] Dong Z., Qu J., Qian G., Zhang Z., Aeolian geomorphological regionalization of the Kumtagh Desert. Journal of Desert Research., 2011, 31, 4, 805-814

[2] Bowler J. M., Aridity in Australia: Age, origins and expression in aeolian landforms and sediments. Earth Science Reviews., $1976,12,2,279-310$

[3] Sun X., and Wang P., How old is the Asian monsoon system?Palaeobotanical records from China. Palaeogeography Palaeoclimatology Palaeoecology., 2006, 222, 4, 181-222

[4] Fitzsimmons K. E., Rhodes E. J., Magee J. W., and Barrows T. T., The timing of linear dune activity in the Strzelecki and Tirari Deserts, Australia. Quaternary Science Reviews., 2007, 26, 19, 2598-2616

[5] Wasson R. J., Fitchett, K., Mackey B., Hyde R., Large-scale patterns of dune type, spacing and orientation in the Australian continental dunefield. Australian Geographer., 1988, 19, 1, 89 . 104

[6] Telfer M. W., Hesse P. P., Perez-Fernandez M., Bailey R. M., Bajkan S., Lancaster N., Morphodynamics, boundary conditions and pattern evolution within a vegetated linear dunefield. Geomorphology, 2017, 290

[7] Bishop M. A., Seasonal variation of crescentic dune morphology and morphometry, Strzeleck-Simpson Desert, Australia. Earth Surface Processes and Landforms., 2010, 26, 7, 783-791

[8] Twidale C. R., Landform development in the Lake Eyre region, Australia. Geographical Review., 1972, 62, 1, 40-70

[9] Marker M. E., and Holmes P. J., Lunette dunes in the northeast Cape, South Africa, as geomorphic indicators of palaeoenvironmental change. Catena., 1995, 24, 4, 259-273

[10] Dong Z., Qian G., Luo W., Zhang Z., Xiao S., and Zhao A., Geomorphological hierarchies for complex mega-dunes and their implications for mega-dune evolution in the Badain Jaran Desert. Geomorphology., 2009, 106, 3, 180-185

[11] Ewing R. C., Gary K., and Lake L. W., Pattern analysis of dunefield parameters. Earth Surface Processes and Landforms., 2010, 31, 9, 1176-1191

[12] Hesse P. P., Magee J. W., and Kaars S. V. D., Late Quaternary climates of the Australian arid zone: a review. Quaternary International., 2004, 118, 1, 87-102

[13] Fitzsimmons K. E., Magee J. W., and Amos K. J., Characterisation of aeolian sediments from the Strzelecki and Tirari Deserts, Australia: Implications for reconstructing palaeoenvironmental conditions. Sedimentary Geology., 2009, 218, 1, 4, 61-73

[14] Wasson R. J., Dune sediment types, sand colour, sediment providence and hydrology in the Strzelecki-Simpson dunefield, Australia. In: Brookfield, M.E., Ahlbrandt T.S. (Eds.). Eolian Sediments and Processes. Elsevier, Amsterdam, 1983, 165-195

[15] Schwerdtfeger P., Curran E. Climate of the Flinders Ranges. In: Davies M., Twidale C. R., Tyler M. J., (Eds.), Natural history of the Flinders Ranges. Royal Society of South Australia, Adelaide, South Australia, 1996, 63-75

[16] Prideaux G. J., Long J. A., Ayliffe L. K., Hellstrom J. C., Pillans B., Boles W. E., Hutchinson M. N., Roberts R. G., Cupper M. L., and Arnold L. J., An arid-adapted middle Pleistocene vertebrate fauna from south-central Australia. Nature., 2007, 44, 7126, 422-425

[17] Tedford R. H., and Wells R. T., Pleistocene deposits and fossil vertebrates from the "Dead Heart of Australia': Memoirs of the Queensland Museum, 1990

[18] Rubin D. M., Lateral migration of linear dunes in the Strzelecki Desert, Australia. Earth Surface Processes and Landforms., 2010, 15,1, 1-14

[19] Bathrellos G. D., Vasilatos C., Skilodimou H. D., Stamatakis M. G., On the occurrence of a pumice-rich layer in Holocene deposits of western Peloponnesus, Ionian Sea, Greece. A geomorphological and geochemical approach. Central European Journal of Geosciences., 2009, 1, 1, 19-32, Doi: 10.2478/v10085009-0006-7

[20] Bathrellos G. D., Skilodimou H. D., Maroukian H., The spatial distribution of Middle and Late Pleistocene Cirques in Greece. Geografiska Annaler: Series A, Physical Geography., 2014, 96, 3, 323-338, Doi: 10.1111/geoa.12044

[21] Liu Y., Yan J., Cen M., Fang Q., Liu Z., and Li Y., A graded index for evaluating precipitation heterogeneity in china. Journal of Geographical Sciences., 2016, 26, 6, 673-693

[22] Ash J. E., and Wasson R. J., Vegetation and mobility in the Australian dunefield. Zeitschrift für Geomorphologie Supplementband., 1983, 45, 7-25

[23] Lancaster N., Palaeoclimatic evidence from sand seas. Palaeo- 
geography Palaeoclimatology Palaeoecology., 1990, 76, 3, 4, 279-290

[24] Bagnold R. A., The Physics of Blown Sand and Desert Dunes. Methuen, London, 1941

[25] Sarnthein M. and Walger E., Der äolische Sandstrom aus der WSahara zur Atlantik küste. Geologische Rundschau., 1974, 63, 1065-1087

[26] Mckee E. D., A study of global sand seas. US Geological Survey Professional Paper 1052, 1979

[27] Sarnthein M., Erlenkeuse H. and Zahn R., Termination I: The response of continental climate in the subtropics as recorded in deep-sea sediments. (Actes du Colloque International CNRS No. 325). Bulletin de l'Institute de Géologie Bassind Áquitaine., 1982, 31, 32, 393-407
[28] Hesse P. P., and Simpson R. L., Variable vegetation cover and episodic sand movement on longitudinal desert sand dunes. Geomorphology., 2006, 81, 3, 4, 276-291

[29] Pye K., and Tsoar H., Aeolian Sand and Sand Dunes, Springer Berlin Heidelberg, 2009

[30] Wasson R. J., and Nanninga P. M., Estimating Wind Transport of Sand on Vegetated Surfaces: Earth Surface Processes \& Landforms., 2010, 11, 5, 505-514

[31] Kamberis E., Bathrellos G. D., Kokinou E., Skilodimou H. D., Correlation between the structural pattern and the development of the hydrographic network in a portion of the Western Thessaly basin (Greece). Central European Journal of Geosciences., 2012, 4, 3, 416-424, Doi: 10.2478/s13533-011-0074-7 